
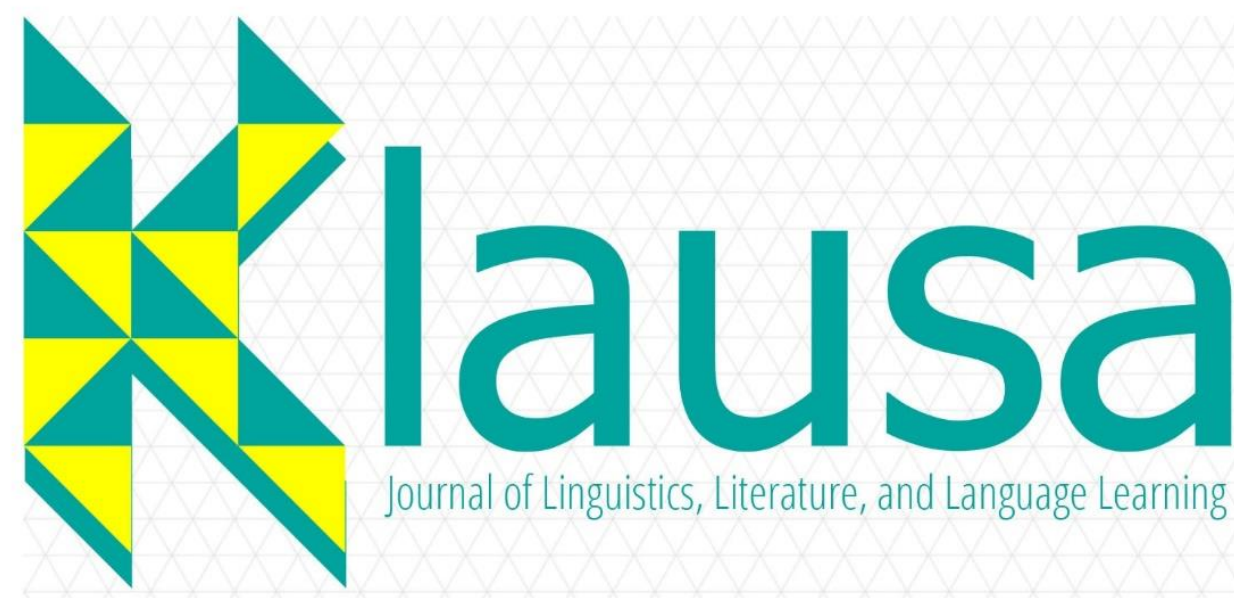

ISNN 2620-9527 Volume 04 Nomor 02

Journal of Linguistics, Literature, and Language Learning

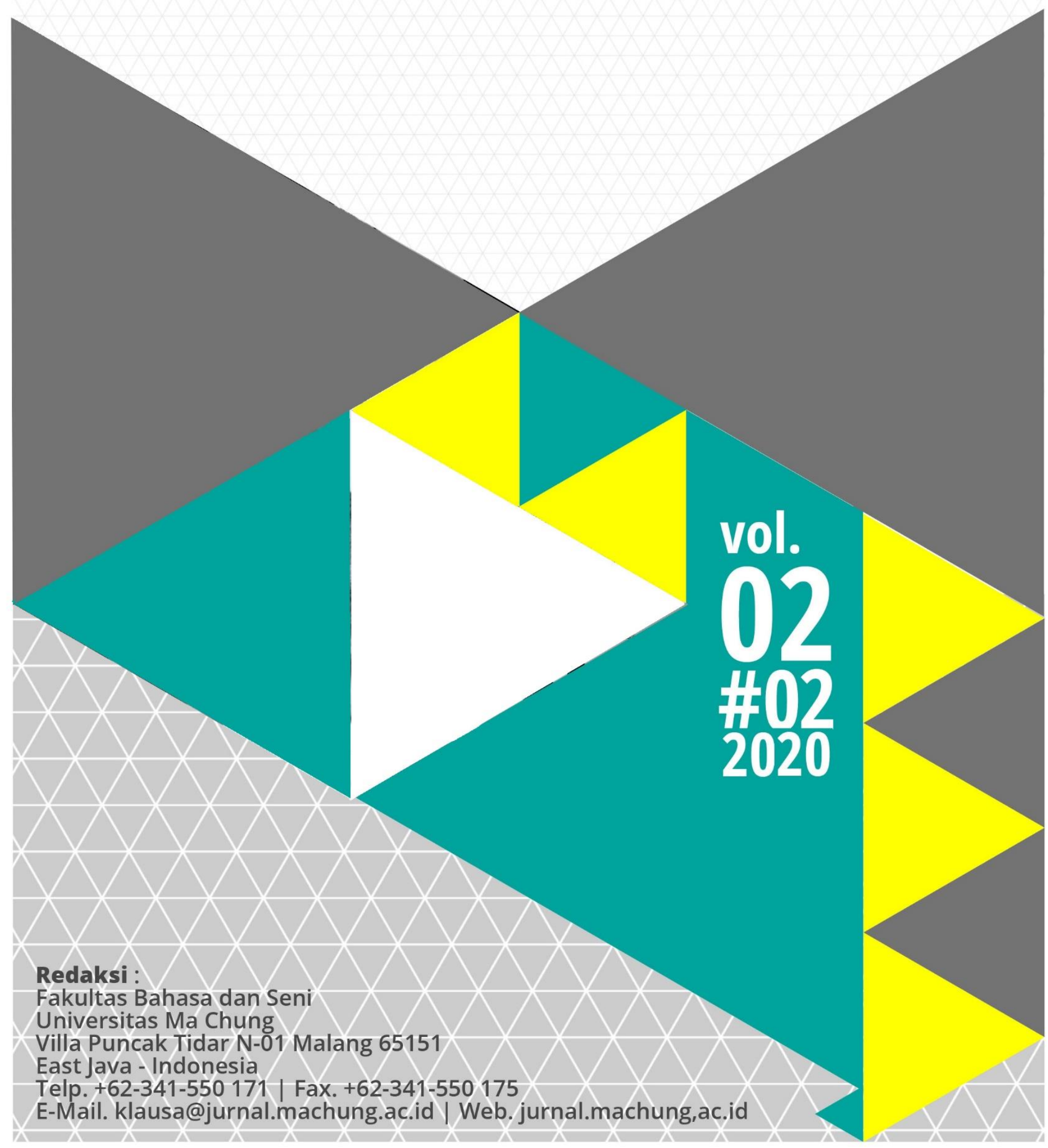


ISSN: $2301-4822(p)$

DOI: $\quad 10.33479 /$ klausa.v4i02

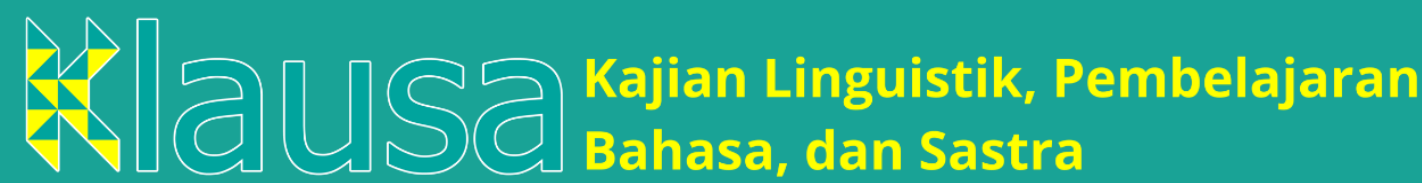

\section{Editorial Team}

\section{Editor-in-Chief}

Journal Manager

Editors

Reviewers

Publisher

Address

Frequency
: $\quad$ Dr. Daniel Ginting

: Wawan Eko Yulianto, Ph.D.

: Prof. Dr. Patrisius I. Djiwandono

Lilis Lestari Wilujeng, M.Hum.

: F.X Dono Sunardi, M.A.

Dhatu Sitaresmi, MTCSOL.

Anggrah Diah Arlinda, MTCSOL.

Yohanna Nirmalasari, S.Pd., M.Pd.

Prof. A. Effendi Kadarisman, Ph.D.

Sisilia Halim, Ph.D.

Dr. Mundi Rahayu

Dr. Ross Wood

Dr. Leticia Araceli Salas Serrano

: Faculty of Language and Arts

Universitsas Ma Chung

: The Faculty of Language and Arts

Ma Chung University

Villa Puncak Tidar N-01 (65151)

Malang, East Java, Indonesia

Email: jurnal.klausa@machung.ac.id

: Twice a year 


\section{CONTENTS}

FOREWORD

iii

(RETRACTED)_PRESUPPOSITION IN THE GUARDIAN NEWS

STORIES: A PRAGMATIC ANALYSIS

Crisnova Katalonika Siahaan ${ }^{1}$, Zia Hisni Mubarak ${ }^{2}$.

FLOUTING MAXIMS IN WHITE HOUSE DOWN

Rebekka Sinaga $^{1}$, Nurma Dhona Handayani ${ }^{2}$ 81

WORD FORMATION IN SHARENA DELON'S INSTAGRAM POSTS: A MORPHOLOGICAL ANALYSIS

Crisnova Katalonika Siahaan¹, Zia Hisni Mubarak² .89

(RETRACTED)_MAXIMS IN JOHN GREEN'S THE FAULT IN OUR STARS: a PRAGMATIC ANALYSIS

Sasmi Saragih $^{1}$, Ambalegin $^{2}$

PENERAPAN CONTENT AND LANGUAGE INTEGRATED LEARNING

(CLIL) PADA PELAJARAN MATEMATIKA DI TINGKAT

PENDIDIKAN DASAR DI INDONESIA

Bebasari Amiroh ${ }^{1}$, Cindy Fortunasari ${ }^{2}$, Daniel Ginting ${ }^{3}$

ANALISIS KUALITAS TERJEMAHAN TEKS BAHASA JEPANG KE

BAHASA INDONESIA DENGAN BING TRANSLATOR

Wisnu Setya Budi ${ }^{1}$, Febi Ariani Saragih ${ }^{2}$

中印姓名比较研究

Anggrah Diah Airlinda ${ }^{1}$

印尼留学生汉语撮口呼韵母偏误分析

Dhatu Sitaresmi ${ }^{1}$ 155 


\title{
FLOUTING MAXIMS IN WHITE HOUSE DOWN
}

\section{Rebekka Sinaga ${ }^{1}$, Nurma Dhona Handayani²}

\author{
${ }^{1}$ Putera Batam University, rebekkasinaga26@gmail.com, \\ ${ }^{2}$ Putera Batam University, nurmadhona@gmail.com
}

\begin{abstract}
Cooperative principles theorized by Grice (1975) explaines the way people use the language well and efficiently. There are four maxims in order to achieve connection during conversation, i.e. the maxims of quality, quantity, relation, and manner. However, people do not always follow and obey the Cooperative principle and instead flout maxim. The aim of this research was to discuss about the types of maxim which were flouted in the movie White House Down written by James Vand Erbilt. As a result, the researcher found 15 samples of flouted maxim, maxim of quantity 4 data, maxim of quality 2 data, maxim of manner 5 data, and 4 data maxim of relation.
\end{abstract}

Keywords: Cooperative Principle, Maxim, Flouting maxim.

\section{INTRODUCTION}

In daily life, language has an important role as a tool for communication. Without language, we can not communicate with other people. In conversation, a speaker says something and then the hearer interprets the meaning. In communication, the speaker will deliver the special message delivered through language and the interlocutor will try to capture the meaning of the message was given. To create good communication, then between speaker and hearer must understand each other well. But sometimes what the speaker said and what the hearer answered is different, but they can understand each other.

In linguistics, it is explained that good communication can be happened by following the "Cooperative Principle" that proposed by Paul Grice. The Cooperative Principle is defined as "make your contribution such as is required, at the stage at which it occurs, by the accepted purpose or direction of the talk exchange in which you are engaged" (Grice, 1975).

Basically the Cooperative Principle explained that in communication every participant said to give contribution well. The intended contribution is to provide information enough to the interlocutor, which are true, clear, coherent, and relevant information talks. In this principle, there are four maxims that must be applied to create good communication, namely maxim of quality, maxim of quantity, maxim of relevance, and maxim of relation. According to Greenall (2006) the concept of maxims is a crucial notion within the theory of the Cooperative Principle. Grice's own characterization of the entity is many-faceted.

In fact, in communication, the four maxims are not always obeyed by the speech participants. When the maxim is not followed or not obeyed in a communication, then this is 
called "Flouting Maxims". In his book, Thomas (1995) said "When flouting a maxim, the speaker does not intend to mislead the hearer but wants the hearer to look for the conversational implicature, that is, the meaning of the utterance is not directly stated in the uttered words". From what Thomas said above, it can be concluded that when the speech participant flouts the maxim in communication, the expert hopes the opponent who has been said could capture the meaning of its words which the message the hearer wanted convey it cannot be stated explicitly. This is because when the maxim is flouted it will bring up the implicature or hidden meaning of the conversation.

There are several phenomena which happened when someone said something but the hearer making a false statement, going out of topic, or making vague statements, but people still can progress. For example in daily life communication we can find there are many flouting maxims, as follows:

Siska: Why do you come late?

Hery: I am hungry

From the conversation above the situation was that Siska was waiting for Hery to come home from school, and when Hery came home from school Siska asked him why he had been coming home from school for a long time and Hery replied he was hungry. From this situation, it can be seen that the flouting maxim occurs.

This research will analyze what maxim is flouted in the film "White House Down" and the reason flouted.

\section{REVIEW OF THE RELATED THEORIES}

The framework of Grice's cooperative principle includes four maxims of quantity, quality, relevance, and manner (Birner, 2013).

\section{Maxim of Quantity}

The category of maxim quantity relates to the amount of information to be given. The first maxim from this category requires one "to be as informative as required". This maxim means the speaker must provide all the information that the hearer wants to understand. If the speaker leaves little important information, the listener will not understand it entirely what the speaker is saying. On the other hand, giving the other person too much information in the course of a conversation may be viewed as superfluous and insignificant. According to the second maxim, that requires a speaker to "be brief", the speaker must avoid unnecessary excessive information in his contribution.

In his book, Peter Grundy gives examples of quantity maxim as follows:

A: Can you tell me what time is it?

B: It's 5 o'clock.

In the example above, it can be clearly seen that the speaker "B" gives information that is needed by "A", so in this case "B" has been obey the quantity maxim in the cooperative principle forward by Grice.

\section{Maxim of Quality}

In this maxim Grice explained that an utterance should be said truly based on what happens in real life. Grice's formulation of the maxim of Quantity has two parts, the first is to 
make your contribution as informative as is required for the current purposes of the exchange. The second is do not make your contribution more informative than is required. The first submaxim has received by far the most attention in the pragmatics literature. Obviously, if the utterance was not based on the reality of what happened.

\section{Maxim of Relation}

The point of this maxim is what the speaker is saying must be related to the previous statement or question. Grice stated that the speaker should be relevant in the conversation. The speakers can not say anything out of topic or what has no correlation with what is being discussed. This maxim is a bridge that connected the interaction between the speaker and the listener. For more clearly, here is an example:

A: Is there a doctor in the house?

B: I'm a doctor.

In the discussion above, it can be seen that the speaker "B" gives relevant information so that the cooperative principle going well between both in a communication.

\section{Maxim of Manner}

Grice stated that the statement must be clear, unambiguous, and concise to achieve the cooperative principle in interaction. That is called maxims of manner. To avoid misunderstanding and ambiguous meaning, the listener must have a relationship, background knowledge, or a little introduction to the topic being discussed. Otherwise, the conversation will not direct the speaker and listener to connect with others. Grundy in his book gives the following example:

A: I heard that you went to the theater last night, what did you see?

B: I watch the drama performance.

In the above discussion, it can be clearly seen that the speaker "B" give clear information to "A" about the question what he is watching the night before. In this case clearly "B" said that he was watching the show. Thus, it can be concluded that the speaker "B" adhere to the maxim of manner.

\section{RESEARCH METHOD}

The research methodology is a guideline system that consists of some elements to solve in research. Therefore it was designed as a descriptive qualitative research proposed by Sudaryanto (2015). The process of research involves emerging questions and procedures. Collecting data in the participants setting. Analyzing the inductively, building from particulars to general themes, and making interpretations of the meaning of data. The final written report has a flexible writing structure.

Qualitative methods are a valuable tool in implementation research because they help to answer complex questions such as how and why efforts to implement best practices may succeed or fail, and how patients and providers experience and make decisions in care (Hamilton \& Finley, 2019). In this research, the writer puts more emphasis on the analysis of flouting in the movie script "White House Down", this research is qualitative. This type of research is "descriptive qualitative research". 


\section{FINDING AND DISCUSSION}

This research examines the type maxim in the movie script "White House Down". Grice's Cooperative Principle is assumed to be a basic concept in pragmatics, yet its interpretation is often problematic (Davies, 2007). From the data, the researches found there are 30 utterances of maxims that flouted in the movie script "White House down". There are maxim quantity flouted 7 times, maxims of quality flouted 9 times, the maxim of manner flouted 5 times, and maxim of relation flouted 9 times.

Table 1. Table of types flouting maxim in "White House Down" movie script.

\begin{tabular}{|c|c|c|}
\hline 1. & Quality & 2 \\
2. & Quantity & 4 \\
3. & Manner & 5 \\
4 & Relation & 4 \\
\hline \multicolumn{2}{|c|}{ Total number of data } & 12 \\
\hline
\end{tabular}

Flouting maxim of quantity

\section{Data 1:}

President : Who are you?

Cale: Don't worry, I'm Secret Service, you're safe, oh shit!

This conversation is the data of flouting maxim of quantity. Because in this situation Cale wanted to save the president in a room and the president asked "who are you?" Cale's answer was too much, he just needed to answer his name.

\section{Data 2:}

Raphelson: Who's the Assistant Director?

Speaker assistant : Wyck Halsey. Also at the White House.

This conversation happened when Raphelson came to the office and asked about the assistant director to the speaker assistant and his answer was flouting maxim of quantity. It could be seen that he gave the long information and he made his contribution more than was required by saying "Also at the White house".

\section{Data 3:}

Raphelson: Alvin, are you okay?

Vice President Hammond : I'm fine, we're just a little shaken up. Do we know what happened yet?

This situation happened when the war began in a white building and Raphelson asked about the condition of Vice President Hammond and his answer was flouting maxim of quantity. It could be seen that he gave the long information and he made his contribution more than was required with too much answer.

\section{Data 4:}

Cale: Did you know about this?

President: I just knew about the tunnel from the pool house that leads back to the Residence. Truman put it in because he didn't want to be photographed in his swim trunks walking back to the house. 
That situation was when they were going to pass through a tunnel and Cale asked the resident if he already knew about the tunnel. And the President replied with a long answer, it was clear that the president flouted maxim of quantity. He should only need to answer "yes" or "no" and then explained it.

\section{Flouting maxim of quality}

\section{Data 1:}

John: You are deputy Special Agent Finnerty?

Carol: Oh, you are Jenna's favor?

From the utterance above, it happened when John came and asked Carol about her. Carol flouted the maxims of quality Because carol did not want to answer John's question like something was hidden.

\section{Data 2:}

Martin: First lady is back tonight?

Friends: Empressid wheels down at 18.45. They're supposed to have private dinner at the residence, but you know how they are?

From the conversation above, it happened when Martin asked about the lady and his friend answered doubtfully uncertain. Here it was clear that his friend flouted maxims of quality. Because he said what he said was uncertain he just still expected it.

\section{Flouting maxim of Manner}

\section{Data 1}

President: You're did all this for money?

Bishop: I have a tumor in my head that's supposed to kill me before Arbor Day.

From the utterances above, the situation was when the president asked Bishop what his intentions and intentions were to do his evil deed was only because of money, and the Bishop replied that he had a tumor on his head so he was forced to do it. Bishop flouted the maxim of manner because he did not answer questions from the president directly, he just immediately made a statement.

\section{Data 2:}

John: Your family in the compound??

President: They didn't come.

From the conversation above shows that John asked about the president's family because he came alone without his family and it made John curious and the president answered directly that his family didn't came, he knew what is the meaning of John's question. The president flouted maxim of manner because his answer is ambiguous.

\section{Data 3:}

Raphelson: John, what are you doing in there?

John: Long story, sir. They've taken the building and are holding hostages. We evaded them so far, but that won't last, so not to put too fine a point on it, but this is the part where you come in here and save us.

This situation happened when Raphelson came to the building and saw a lot of damage. When Raphelson asked "John, what are you doing in there?" John replied "Long story, sir. They've taken the building and are holding hostages. We evaded them so far, but that won't 
last, so not to put too fine a point on it, but this is the part where you come in here and save us". It is clear that John flouted maxim of manner. The reason is John did not give the relevance answer based on the question that Raphelson asked.

\section{Data 4:}

John: Jenna, Jenna. Did you get me in

Jenna: What do I get if I did?

From the data showed the conversation between Jenna and John, Jenna's answer flouted the maxims of manner because she was supposed to answer John's question instead of asking back, it means she wanted attention from John.

\section{Data 5:}

President's Wife : How's it going there?

President: Rophelson is the key.

From the conversation above shows that president's wife asked the president about their friend and he answered directly "Raphelson is the key", and president flouted maxim of manner because his answer were ambiguous and not clear.

\section{Flouting maxim of relation}

\section{Data 1}

Emily: Did you know the white house used to be called the president's palace?

John: Look, I need you to hear me right now.

From the conversation above, it happened when Emily came and asked John about the white house but John answered was not relevant. Here John has broken the maxims of relation. It can be seen that at that moment John was upset with Emily because she did not listen to John said.

\section{Data 2:}

President: When the last time you took a day off?

Wife: Oh I am fine.

This conversation happened when the president asked his wife about her condition was not good and his wife answered that she was good. His wife had understood the president intentions and she tried to make sure that she was fine. She tried to hide it from her husband. The president wife flouted the maxims of relation.

\section{Data 3:}

Cale : Good point. Do you have a cell phone?

President : I have a better idea.

This situation happened when Cale and president stucked when cale wanted to save the president, and cale asked if the president had a cellphone, and the president replied that he had other ideas. It showed that at that time the president did not have a cellphone and indirectly he had flouted the maxim of relations.

\section{Data 4:}

Bishop: You have a Threat Matrix for us?

Finnerty: Homeland says a guy they were sitting on in Toronto went missing 36 hours ago, they think he might have crossed.

From the conversation above Finnerty flouts maxim of relation. The reason is because Bishop asked "You have a Threat Matrix for us?" and the Finnerty answered "Homeland says 
a guy they were sitting on in Toronto went missing 36 hours ago, they think he might have crossed" there are no relation between Bishop question with Finnerty answer but Bishop understood what he meant.

\section{CONCLUSION AND SUGGESTION}

\section{Conclusion}

Grice's theory influenced the effectiveness of conversation on "White House Down" movie. As is known for maxims in this movie deliberately made to set the storyline. From the results of research, researchers found several types of maxim that is in the movie script "White House Down". Among of them are maxim of Quantity, maxim of Quality, maxim of Manner and maxim of Relation. And the results obtained from the most dominant maxim of quality and relations are widely used. Although there are so many maxims were flouting but the movie still enjoyed by the viewers.

\section{Suggestion}

Based on the result of the research, the researcher want to give some suggestion that is, to pay more attention to the way the speaker speak so that the hearer does not misunderstand what the speaker is saying.

\section{REFERENCES}

Birner, B. J. (2013). Introduction to pragmatics. Blackwell.

Davies, B. L. (2007). Grice's cooperative principle: Meaning and rationality. Journal of Pragmatics, 39(12), 2308-2331. https://doi.org/10.1016/j.pragma.2007.09.002

Greenall, A. K. (2006). Maxims And Flouting. Encyclopedia of Language \& Linguistics, 545548. https://doi.org/10.1016/B0-08-044854-2/00361-8

GRICE.1991.Studies in the Way of Words.pdf. (1989). London: Library of Congress Cataloging in Publication Data.

Hamilton, A. B., \& Finley, E. P. (2019). Qualitative methods in implementation research: an introduction. Psychiatry Research, $280, \quad 112516$. https://doi.org/10.1016/j.psychres.2019.112516

White, A. R. (1990). Studies in the Way of Words By Paul Grice Harvard University Press, 1989. Philosophy, Vol. 65, pp. 111-113. https://doi.org/10.1017/s0031819100064330

Grice, H. P. (1975). Logic and conversation. New York: Academic Press.

Sudaryanto. (2015). Metode dan aneka teknik analisis bahasa. Yogyakarta: Sanata Dharma University Press.

Thomas, Jenny. (1995). Meaning in Interaction: An Introduction to Pragmatics. Harlow: Pearson Education. 
